\title{
Correction to: Dissemination of Direct Instruction: Ponder These while Pursuing That
}

\author{
Patrick C. Friman ${ }^{1}$
}

Published online: 19 August 2021

(C) Association for Behavior Analysis International 2021

\section{Correction to: Perspectives on Behavior Science https://doi.org/10.1007/s40614-021-00285-Z}

Due to an error in processing after the author had reviewed proofs, two paragraphs were incorrectly removed from this article on its initial publication. The article has been updated to reinstate paragraphs in the sections "The Behavioral Dynamics of Training" and "Politics".

SpringerNature regrets this error.

Publisher's Note Springer Nature remains neutral with regard to jurisdictional claims in published maps and institutional affiliations.

The online version of the original article can be found at https://doi.org/10.1007/s40614-021-00285-z

Patrick C. Friman

Patrick.friman@boystown.org

1 Center for Behavioral Health, Boys Town and the University of Nebraska School of Medicine, 13460 Walsh Drive, Boys Town, NE 68010, USA 